\title{
Comparison of ICT Development in V4 Countries
}

\author{
Martina KUNCOVÁ, Petr DOUCEK \\ University of Economics, Prague, Czech Republic \\ \{martina.kuncova, petr.doucek\}@vse.cz
}

\begin{abstract}
The development of the companies, society or economy is nowadays closely connected with ICT. The increase of the technological options and the ICT development leads to higher demand for technical equipment but also for the IT knowledge. In global economy, the changes and trends in one country influence other countries in their development. As the ICT level has a huge impact on so-called digital economy or on Industry 4.0 (especially in changing the business models as a tool in changing the impact of ICT on economy) the aim of this paper is the comparison of the ICT development in V4 countries. The comparison focuses on the competitiveness of countries in technological readiness and the position of countries in the digital economy and society. Results of our multidimensional evaluation present the conclusion that the Czech Republic occupies the leading position among V4 countries in competitiveness in technological readiness. The most lagging country has been identified Poland in investigated factors.
\end{abstract}

Keywords: ICT, Digital Agenda, Comparison of Countries.

\section{Introduction}

Information and communication technologies (ICT) belong to the necessary basics for the everyday life of nearly each company or each person in the developed society. Internet, various online communication tools, social networks, data repositories, etc., are becoming a common part of life. Thus, new concepts such as "Digital Economy" or "Industry 4.0" which is related to the expansion of ICT in society come into being. Digital economy is related with the huge expansion of the usage of computers, laptops, tablets, smart mobile phones, and similar devices, and broader internet connectivity [17]. The digital economy now permeates lot of aspects of the world economy, impacting sectors as varied as media, energy, transportation, mechanical engineering, industry, banking, retail, education, publishing or healthcare. ICT are transforming the ways social interactions and personal relationships are conducted, with fixed, mobile and broadcast networks converging, and devices and objects increasingly connected to form the Internet of Things [16].

The necessity to be online changes the behavior of people and companies. In the Czech Republic, the material of the updated State Policy on Electronic Communications - Digital Czech Republic v. 2.0, The Road to Digital Economy was 
approved in 2013. It supports the construction of high-quality infrastructure including high-speed Internet access, digital services development and digital literacy [14].

New forms of business are emerging and digital information and its transmission becomes a major business advantage [21]. As a result, the new concept, Industry 4.0, sometimes called the Internet Things [2] or the Fourth Industrial Revolution, has also started to be important for the future development. Most of the developed countries react in preparation of Industry 4.0 programmes - in the Czech Republic it is the National Industry Initiative 4.0 [13].

ICT and their implementation in economic practice are changing both existing process models and actual business models. The changes in these models are analyzed by major consulting and advisory companies. Also, the Massachusetts Institute of Technology IT has developed a respective approach in cooperation with Deloitte [11]. Beyond those broad models there are also models focusing on specific issues such as electronic invoicing processes [3] or electronic procurement [5, 10, 22]. Models focusing on new business models pertain in particular to the concept of industry 4.0 as e.g. presented by Basl \& Sasiadek [1] or in Zimmermann [25]. This concept is also reflected in a new concept of socially responsible development [17], which then reflects for example in the concept of Smart Cities. Other research papers examine the impact of ICT on the economy [4], ICT development and ICT level comparisons in selected countries [15], the impact on economic growth [8] or on the economic system as a whole [6]. Comparison of countries by selected ICT-indexes was analyzed for example by Kuncová and Doucek [12]. The Czech Republic, Slovakia and Hungary were also compared from the ICT point of view to show the evidence of stock market reaction to ICT investment [9]. List of other articles aimed at ICT in V4 countries can be found in the paper of Piotrowicz [19].

This paper focuses on the comparison of the ICT level in the Czech Republic, Slovakia, Hungary and Poland, ie. V4 countries (Visegrad Group). The aim of the analysis is to determine the extent to which the development of ICT in the Czech Republic has shifted to companies, state administration or among ordinary citizens and how the Czech Republic is in the use of ICT services compared to selected countries, namely its closest neighbors.

\section{$2 \quad$ Data and methodology}

Variety of statistics and surveys could be used to compare ICT in selected countries. The data used in the following comparison comes mainly from the Eurostat databases [7] and from the documents The Global Competitiveness Reports (2009-2016) [22] and the Europe Competitiveness Report [24]. Each of these documents compares selected countries from multiple points of view using different methodologies. The Global Competitiveness Report identifies the so-called Global Competitiveness Index (GCI), an index of the overall competitiveness of countries, which includes 12 basic pillars (Table 1). Out of them the $9^{\text {th }}$ pillar covers 9 parts aimed at ICT (Table 2). It accounts for $17 \%$ of the GCI. 
Table 1. Pillars of the Global Competitiveness Index [22].

\begin{tabular}{ll}
\hline No. & Name \\
\hline 1. & Institutions \\
2. & Infrastructure \\
3. & Macroeconomics Environment \\
4. & Health and primary education \\
5. & Higher education and training \\
6. & Goods market efficiency \\
7. & Labor market and efficiency \\
8. & Financial market development \\
9. & Technological readiness \\
10. & Market size \\
11. & Business sophistication \\
12. & Innovation \\
\hline
\end{tabular}

The second index that is aimed at measuring competitiveness of the European countries is the Europe 2020 Competitiveness Report. It focuses on three core areas:

- Smart growth,

- Sustainable growth,

- Inclusive growth.

Inside the areas 7 different flagship initiatives are mentioned, one of them Digital agenda. Digital agenda belongs to the first area (Smart growth) and accounts for $25 \%$ of this part and $14 \%$ of the total score.

Table 2. Parts of the $9^{\text {th }}$ pillar of the Global Competitiveness Index [22].

\begin{tabular}{|l|}
\hline 9. Technological readiness \\
\hline 9.01 Availability of latest technologies \\
\hline 9.02 Firm-level technology absorption \\
\hline 9.03 FDI and technology transfer \\
\hline 9.04 Internet users \\
\hline 9.05 Broadband Internet subscription \\
\hline 9.06 Internet bandwidth \\
\hline 9.07 Mobile broadband subscription \\
\hline 2.08 Number of telephone lines \\
\hline 2.09 Mobile telephone subscription \\
\hline
\end{tabular}


Data from Eurostat [7] is also focused on the Digital Economy and Society, which includes four main parts:

- Use of ICT by households and individual users,

- The use of ICT in companies,

- Digital skills,

- ICT sector.

The first part is further divided into 5 areas (Internet access and computer use, Internet use, E-commerce, E-government, Regional ICT statistics), which are further divided into a total of 35 indicators. The second part of business data includes 3 domains (E-commerce, Internet connection, E-business) containing a total of 8 indicators. The Digital skills Section contains only one subset (ICT users) divided into 9 indicators. The last ICT sector does not have any sub-areas, only 3 indicators are listed.

For the comparison of the situation in the V4 countries, data of the 2014 year were mainly used but to see the development during 5 years period, sometimes also data from 2009 year were used.

Each area was evaluated separately via TOPSIS method that belongs to the multicriteria evaluation of alternatives methods [20]. The basic concept of the TOPSIS (Technique for Order Preference by Similarity to Ideal Solution) method is that the best alternative should have the shortest distance from the ideal solution (taken from the alternatives compared) and the farthest from the non-ideal alternative. The method is also able to rank the alternatives using the relative index of distance of the alternatives from the basal alternative. Higher relative index of distance means better alternative. As the GCI and European Report index has its own scale 1-7 for all criteria it is not necessary to use any other method for multi-criteria evaluation, but the Eurostat data is in various units and scales and that is why the TOPSIS method is applied on all criteria including the indexes to be able to compare them.

The results were then summarized for overall evaluation of the whole area in Digital agenda, Technological readiness and Digital Economy and Society. The main aim is not only to compare the countries and analyse the changes during years but also to see if there is any difference in the country ranking according to what ICT data are used.

\section{$3 \quad$ Results and discussion}

First of all, the share of ICT sector on GDP and its development since 2009 till 2014 is compared. Fig. 1 shows that the trends in all V4 countries were more or less stable without big increase/decrease. The best country from this point of view was Hungary followed by the Czech Republic, Slovakia and the last one was Poland. The share was formed mainly by ICT services in all countries - from $70 \%$ in Hungary to $90 \%$ in the Czech Republic. The similar situation was in the number of persons employed in the ICT sector as \% of the total employment where the highest percentage share was 
in Hungary (about 3.5\%) - Table 3. Data show small increase during 5 years in the Czech Republic and Hungary (about 1-2\% increase) and higher increase in Poland and Slovakia (about 25\%) but this change does not improve the position of these countries as they were worse than the first two ones.

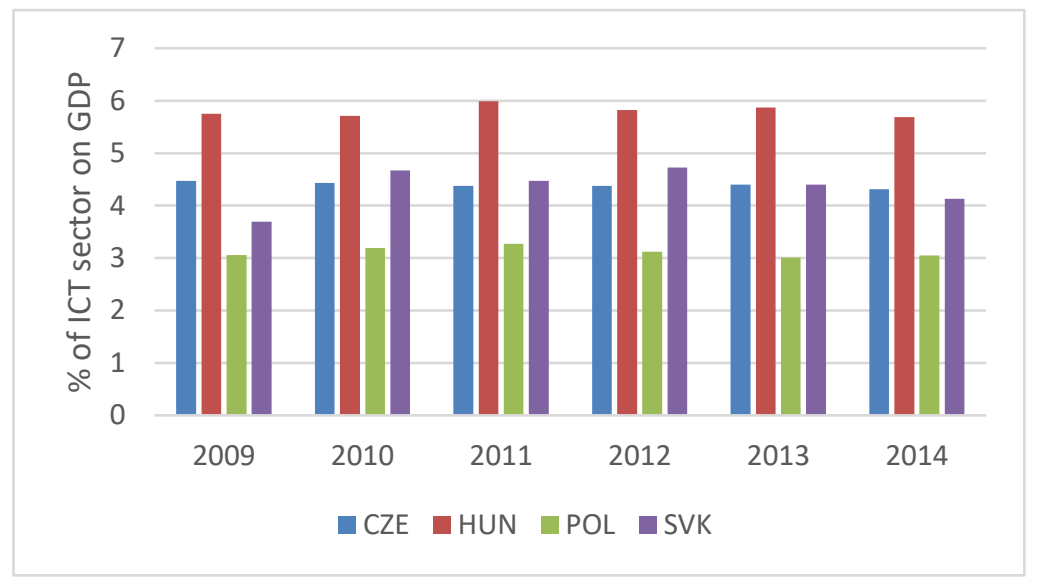

Fig. 1. Share of the ICT sector on GDP in V4 countries in the years 2009-2014 [7].

Table 3. Percentage of the ICT personnel on total employment [7].

\begin{tabular}{l|c|c|c|c|c|c}
\hline Total & $\mathbf{2 0 0 9}$ & $\mathbf{2 0 1 0}$ & $\mathbf{2 0 1 1}$ & $\mathbf{2 0 1 2}$ & $\mathbf{2 0 1 3}$ & $\mathbf{2 0 1 4}$ \\
\hline $\begin{array}{l}\text { Czech } \\
\text { republic }\end{array}$ & 2.76 & 2.7 & 2.79 & 2.79 & 2.76 & 2.81 \\
\hline Hungary & 3.37 & 3.63 & 3.69 & 3.65 & 3.54 & 3.41 \\
\hline Poland & 1.58 & 1.71 & 1.76 & 1.84 & 1.91 & 2 \\
\hline Slovakia & 2.2 & 2.72 & 2.85 & 2.79 & 2.78 & 2.77 \\
\hline
\end{tabular}

Next part of the analysis is aimed at the Digital agenda score taken from the European Competitiveness Report (Table 4). According to the score on the scale 1-7 the best two were again the Czech Republic and Hungary, the worst seemed to be Slovakia. The order of these countries from 2014 is not good as all 4 were in the worse part of the European Union.

Digital agenda is formed by 3 indicators: ICT readiness formed by 6 criteria, ICT usage (4 criteria) and ICT impact (4 criteria). For the comparison of countries TOPSIS method was used first to evaluate the countries in each indicator separately and afterwards the results of the indicators were used as new criteria for $2^{\text {nd }}$ TOPSIS analysis. The results are in Table 5. Hungary was the best in ICT impact (mainly in ICT PCT patents, applications/million pop.) and ICT usage (with the best value in Government Online Service Index which was $70 \%$ compared to $50 \%$ of other countries) but it was poorer in ICT readiness. That is why finally it is at the second place close to the Czech Republic. This country was the best one in ICT readiness, 
especially in Internet bandwidth (kb/s per user) with 100.1 meanwhile in Hungary it was only 15 . Poland was the worst one in ICT usage (worst values in all 4 criteria), Slovakia in ICT impact. The results of the TOPSIS method coincide with the Digital agenda score (although for the score different principle was used).

Table 4. Comparison of the countries - Digital agenda, year 2014 [24].

\begin{tabular}{l|c|c}
\hline Country & Ranking (out of EU28) & Score (scale 1-7) \\
\hline Czech republic & 17 & 4.31 \\
\hline Hungary & 21 & 4.3 \\
\hline Poland & 23 & 3.98 \\
\hline Slovakia & 27 & 3.71 \\
\hline
\end{tabular}

Table 5. TOPSIS analysis results - Digital agenda 2014.

\begin{tabular}{c|c|c|c|c}
\hline Country & \multicolumn{1}{c}{$\begin{array}{c}\text { ICT } \\
\text { readiness }\end{array}$} & \multicolumn{1}{c}{$\begin{array}{c}\text { ICT } \\
\text { usage }\end{array}$} & \multicolumn{1}{c}{$\begin{array}{c}\text { ICT } \\
\text { impact }\end{array}$} & \multicolumn{1}{c}{$\begin{array}{c}\text { Final } \\
\text { score }\end{array}$} \\
\hline $\begin{array}{c}\text { Czech } \\
\text { republic }\end{array}$ & 0.77486 & 0.47575 & 0.47012 & 0.67765 \\
\hline Hungary & 0.23218 & 0.65175 & 0.93010 & 0.64413 \\
\hline Poland & 0.66197 & 0.00000 & 0.20042 & 0.32476 \\
\hline Slovakia & 0.17197 & 0.43397 & 0.07213 & 0.31809 \\
\hline
\end{tabular}

GCI index measures the competitiveness in all 12 pillars and the $9^{\text {th }}$ of them is connected with ICT - it is Technological readiness with its 9 criteria. Nearly all V4 countries had better position (except of Poland) and better score in $9^{\text {th }}$ pillar of GCI than in GCI itself (Table 6) so they were better in technological readiness than in other pillars together. At first glance the results differ in the position of Poland (better than in Digital agenda) and Hungary (worse than in Digital agenda). When all $9^{\text {th }}$ GCI pillar parts were taken as criteria for the comparison via TOPSIS, we see the same order (Table 7) that the best country in both years was the Czech Republic followed by Poland (which was closer in 2014 than in 2009) whilst Hungary and Slovakia were relatively far. Comparing all countries in both years together the best were the Czech Republic and Poland in 2014 followed by the Czech Republic and Poland in 2009 and then the other two countries appear. The biggest change between 2009 and 2014 can be seen in the criterion "Number of telephone lines" which increased by $390 \%$ (Hungary) or $607 \%$ (Poland) and 628\% (Czech Republic). Another big increase can be registered in the criterion "Internet bandwidth" with $128 \%$ (Slovakia) or $310 \%$ (Poland) and 380\% (Hungary) increase since 2009 till 2014. Other criteria were more or less stable with no big change between years. In all 4 countries, the decrease about $3-8 \%$ during 5 years can be seen in the criteria "Availability of latest technologies", "Firm-level technology absorption" and "FDI and technology transfer". This situation indicates a deterioration or loose in comparison with the developed countries. The better position of Poland was caused by the fact that the criteria "Mobile broadband subscription" and "Number of telephone lines" where Poland was the best country 
had higher weight in GCI $9^{\text {th }}$ pillar $(22 \%)$ whilst in Digital agenda they influence only the indicator ICT readiness (where Poland was also the second best country) but in the other two areas (ICT usage, ICT impact) Poland was the worst (or second worst) one.

Table 6. Comparison of the countries from the GCI point of view, year 2014 [22].

\begin{tabular}{lcccc}
\hline Country & $\begin{array}{c}\text { GCI } \\
\text { rank }\end{array}$ & $\begin{array}{c}\text { GCI } \\
\text { Score (1-7) }\end{array}$ & $\begin{array}{c}\text { GCI 9. pillar } \\
\text { rank }\end{array}$ & $\begin{array}{c}\text { GCI 9. pillar } \\
\text { Score (1-7) }\end{array}$ \\
\hline $\begin{array}{l}\text { Czech } \\
\text { republic }\end{array}$ & $\mathbf{3 1 .}$ & 4.69 & 29. & 5.43 \\
\hline Poland & $\mathbf{4 1 .}$ & 4.49 & 41. & 4.78 \\
\hline Hungary & $\mathbf{6 3 .}$ & 4.25 & 48. & 4.6 \\
\hline Slovakia & $\mathbf{6 7}$ & 4.22 & 44. & 4.64 \\
\hline
\end{tabular}

Table 7. TOPSIS results for GCI $9^{\text {th }}$ pillar - Technological readiness.

\begin{tabular}{l|cc}
\hline Country & Score 2009 & Score 2014 \\
\hline Czech republic & 0.77227 & 0.68140 \\
\hline Poland & 0.52194 & 0.51227 \\
\hline Slovakia & 0.28057 & 0.28702 \\
\hline Hungary & 0.25342 & 0.39362 \\
\hline
\end{tabular}

For the last comparison, the data from Eurostat - Digital Economic and society was used. As it was mentioned before it covers 4 parts (each with several criteria):

- Use of ICT by households and individual users,

- The use of ICT in companies,

- Digital skills,

- ICT sector.

The first area covers the usage of internet by households and individual users, especially criteria like "Connection to the Internet", "Computer use", "E-commerce", "E-government" etc. As opposed to previous comparisons Slovakia was the best country in 2014 (mainly because of the E-commerce). In the same area, the Czech Republic had the worst results (mainly because of the E-commerce). Although in the $3^{\text {rd }}$ and $4^{\text {th }}$ area Slovakia was again the best country. It is because the $3^{\text {rd }}$ area "digital skills" is aimed at the computer and internet usage of individuals (how many activities related to computer or internet the individual carried out) so if only 2 criteria (instead of 9) were used (with the highest number of activities at internet/computer), the Czech Republic or Hungary would be on the top. The $4^{\text {th }}$ area has only 3 criteria in which Slovakia is not the best one but as it is not poor in any of these criteria, the method put it into the first place. Only the $2^{\text {nd }}$ area (ICT usage by enterprises) is different, the Czech Republic seems to be the best one (because of the best values in E-commerce and Connection to the internet). In total score Slovakia was the best country but only 
because of the equal weights of all criteria. As the data differ from the previous analysis (households and enterprises were separated, criteria for skills were added), the final order is also different.

Table 8. Comparison of the countries - Digital economic and society, 2014 [7].

\begin{tabular}{|c|c|c|c|c|c|}
\hline $\begin{array}{l}\text { Rank } \\
\text { (TOPSIS } \\
\text { results) }\end{array}$ & $\begin{array}{l}\text { 1. area } \\
\text { Househ. }\end{array}$ & $\begin{array}{l}\text { 2. area } \\
\text { enterpr. }\end{array}$ & $\begin{array}{c}\text { 3. area } \\
\text { digital skills }\end{array}$ & $\begin{array}{c}\text { 4. area } \\
\text { ICT sector }\end{array}$ & Total \\
\hline $\begin{array}{l}\text { Czech } \\
\text { republic }\end{array}$ & $\begin{array}{c}4 . \\
(0.221)\end{array}$ & $\begin{array}{c}1 . \\
(0.739)\end{array}$ & 3. $(0.505)$ & $\begin{array}{c}4 . \\
(0.302)\end{array}$ & $\begin{array}{c}2 . \\
(0.502)\end{array}$ \\
\hline Poland & $\begin{array}{c}2 . \\
(0.363)\end{array}$ & $\begin{array}{c}3 . \\
(0.279)\end{array}$ & 2. $(0.514)$ & $\begin{array}{c}3 . \\
(0.333)\end{array}$ & $\begin{array}{c}4 . \\
(0.266)\end{array}$ \\
\hline Hungary & $\begin{array}{c}3 . \\
(0.239)\end{array}$ & $\begin{array}{c}4 . \\
(0.090)\end{array}$ & 4. $(0.185)$ & $\begin{array}{c}2 . \\
(0.667)\end{array}$ & $\begin{array}{l}3 . \\
(0.295)\end{array}$ \\
\hline Slovakia & $\begin{array}{c}1 . \\
(0.978)\end{array}$ & $\begin{array}{c}2 . \\
(0.389)\end{array}$ & 1. $(0.647)$ & $\begin{array}{c}1 . \\
(0.684)\end{array}$ & $\begin{array}{c}1 . \\
(0.711)\end{array}$ \\
\hline
\end{tabular}

\section{Conclusions}

The aim of the paper was to assess the situation in ICT and the digital economy in the V4 countries. Countries were compared on the basis of various indexes and ICT indicators aimed at the technological readiness, digital agenda, and from the point of view of the digital economy and society. The paper did not aim at the explanation of the reasons for the situation in ICT in individual countries. The results obtained indicate that the V4 countries were not among the top EU countries in the field of ICT, mainly in the use of the Internet by households, the digital knowledge of people, the availability of the latest technologies and their use by companies. The Czech Republic was particularly successful at the corporate level in the area of E-commerce and internet connection of companies. From the households point of view there was also a big problem with the so-called E-government agenda, where the Czech Republic was below the EU average and it was third in 2014 from V4 countries. Nevertheless, the level of ICT measured by GCI index was slightly higher in the Czech Republic than in the V4 countries, and especially firms were well prepared for activities related to the development of Industry 4.0. On the other hand, the share of ICT on GDP was highest in Hungary and the households or individual usage of internet and computers seemed to be the best in Slovakia. Only Poland was not at the V4 top from any ICT point of view. The future comparison with other developed EU countries (especially Germany) could show where the main problems in the ICT development are.

Acknowledgements. Paper was processed with contribution of long term support of scientific work on Faculty of Informatics and Statistics, University of Economics, 
Prague (IP 400040) and by the by grant IGA 57/2017 (IG 403057) of the Faculty of Informatics and Statistics, University of Economics, Prague.

\section{References}

1. Basl, J., Sasiadek, M.: Comparison of Industry 4.0 Application Rate in Selected Polish and Czech Companies. IDIMT-2017, Digitalization in Management, Society and Economy, pp.401-410, Linz: Trauner Verlag Universität (2017)

2. Buyya, R., Dastjerdi, A.V. eds: Internet of Things: Principles and Paradigms. Morgan Kaufmann, Amsterdam Boston Heidelberg (2016).

3. Cuylen, A., Kosch, L., Breitner, M. H.: Development of a maturity model for electronic invoice processes. Electronic Markets - The International Journal on Networked Business, 26(2), 115-127 (2015)

4. Delina, R. et al.: Vplyv informačných a komunikačních technologií na ekonomické prostredie. Systémová integrace. 16(1), 27-48 (2009).

5. Delina, R., Sukker, A. A. M.: The Significance of Transparency in Electronic Procurement. IDIMT-2015 - Information Technology and Society Interaction and Interdependence. pp. 237-246, Linz: Trauner Verlag Universitet (2015)

6. Doucek, P., Maryška, M. et al.: Konkurenceschopnost českého ICT sektoru. Professoional Publishing, Prague (2012).

7. Eurostat: Digital Economy and Society Statistics. [online], Available at: http://ec.europa.eu/eurostat/web/digital-economy-and-society/data/main-tables, last accessed 2017/10/20.

8. Hančlová J. et al.: Does ICT capital affect economic growth in the EU-15 and EU-12 countries? Journal of business economics and management. 16(2), 387-406 (2015).

9. Janke, F., Packová, M.: Impact of ICT investments on performance of companies in transition economies: Evidence from Czech Republic, Hungary and Slovakia. Quality, Innovation, Prosperity XVII (2), 9-21 (2013).

10. Johansson, B., Sudzina, F., Pucihar, A.: Alignment of Business and Information Strategies and its Impact on Business Performance. Journal of Business Economics and Management. 15(5), 886-898 (2014)

11. Kane, G. C., Palmer, D., Phillips, A. N., Kiron, D., Buckley, N.: Strategy, not Technology, Drives Digital Transformation. MIT Sloan Management Review. [online], Available at: http://sloanreview.mit.edu/projects/strategy-drives-digital-transformation/ last accessed 2017/11/15.

12. Kuncová, M., Doucek, P.: Využívání ICT v České republice ve srovnání s evropskými zeměmi. Regionální studia, 1, 67-81 (2011).

13. Mařík, V. et al.: Národní iniciativa Průmysl 4.0. [online], Available at: http://kzps.cz/wpcontent/uploads/2016/02/kzps-cr.pdf, last accessed 2017/10/15.

14. Ministry of Industry and Trade - Digitální Česko v. 2.0, Cesta k digitální ekonomice. [online], Available at: https://www.mpo.cz/dokument127530.html, last accessed 2017/10/15.

15. Novotný, O. et al.: Digitální cesta k prosperitě. 1.ed. PROFESSIONAL PUBLISHING, Prague (2011).

16. OECD: Digital Economy Outlook 2015. [online], Available at: http://dx.doi.org/10.1787/9789264232440-en last accessed 2017/11/15. 
17. Pavlíček, A., Doucek, P.: Corporate Social Responsibility in Social Media Environment. Information and Communication Technology. pp. 323-332, London: Springer International Publishing (2015) DOI: 10.1007/978-3-319-24315-3_33.

18. Pilný, I.: Digitální ekonomika. BizBooks, Brno (2016).

19. Piotrowicz, W. Information Technology and Systems in the Visegrád Group of Countries (Czech Republic, Hungary, Poland, and Slovakia): A Literature Review. Journal of Global Information Technology Management, 18(2), 77-93 (2015).

20. Triantaphyllou, E.: Multi-Criteria Decision Making Methods: a Comparative Study (Applied Optimization - vol.44). Kluwer Academic Pub (2000).

21. Valenduc, G., Vendramin, P.: Work in the digital economy: sorting the old from the new. [online], Available https://dial.uclouvain.be/pr/boreal/object/boreal\%3A173373/datastream/PDF_01/view, last accessed 2017/10/17.

22. Versendaal, J., van den Akker, M., Xing, X., de Bevere, B.: Procurement maturity and ITalignment models: overview and a case study. Electronic Markets - The International Journal on Networked Business, 23(4), 295-306 (2013)

23. World Economic Forum: The Global Competitiveness Report 2009-2016. [online], Available at: https://www.weforum.org/reports, last accessed 2017/10/12.

24. World Economic Forum: The European 2020 Competitiveness Report, 2014 [online], Available http://www3.weforum.org/docs/WEF_Europe2020_CompetitivenessReport_2014.pdf, last accessed 2017/10/12.

25. Zimmerman, H.D.: Digital Transformation - The Emerging Digital Economy. Liberecké informatické fórum, pp. 139- 147, Liberec: TUL (2016) 